\title{
The associations that income, education, and ethnicity have with birthweight and prematurity: how close are they?
}

\author{
Ana Daniela Izoton de Sadovsky, ${ }^{1}$ Keila Cristina Mascarello, ${ }^{2}$ Angelica Espinosa \\ Miranda, ${ }^{3}$ and Mariangela F. Silveira ${ }^{4}$
}

Suggested citation
Sadovsky ADI, Mascarello KC, Miranda AE, Silveira MF. The associations that income, education, and
ethnicity have with birthweight and prematurity: how close are they? Rev Panam Salud Publica. 2018;42:e92. https://doi.org/10.26633/RPSP.2018.92

ABSTRACT Objectives. To identify evidence that income, education, or ethnicity might be associated with low birthweight, small-for-gestational-age birth, or preterm birth.

Methods. A systematic review was conducted using searches in two online databases, PubMed and Literature in the Health Sciences in Latin America and the Caribbean (LILACS). The searches covered materials published between 1 January 1982 and 5 May 2016. The search terms used were ("infant, premature" OR "infant, small for gestational age" OR "fetal growth retardation") AND ("socioeconomic factors" OR "ethnic groups" OR "maternal age").

Results. A total of 3070 references that met the initial selection criteria were analyzed, and 157 relevant studies were fully read. We located 18 studies that investigated associations of family or maternal income, education, or ethnicity with low birthweight, small-for-gestationalage birth, or preterm birth. Of the 18, 10 of them involved high-income countries, and 8 dealt with middle- or low-income countries. Greater evidence was found for an association between ethnicity and the three outcomes studied, particularly for prematurity among children of black mothers. There was little evidence for an association between maternal/family income or education and any of the three outcomes.

Conclusions. Income and education weren't determinants for low birthweight, smallfor-gestational-age birth, or preterm birth. However, black ethnicity was strongly associated with the three outcomes, especially with prematurity.

Keywords Income; education; ethnic groups; fetal growth retardation; infant, premature.

\footnotetext{
Department of Pediatrics, Federal University of Espírito Santo, Vitória, Espírito Santo, Brazil. Send correspondence to Ana Daniela I. de Sadovsky at adisadovsky@gmail.com

2 Department of Health Sciences, Federal University of Espírito Santo, Vitória, Espírito Santo, Brazil.

3 Postgraduate Program in Public Health, Federal University of Espírito Santo, Vitória, Espírito Santo, Brazil.

4 Postgraduate Program in Epidemiology, Federal University of Pelotas, Pelotas, Rio Grande do Sul, Brazil.
}

Appropriate intrauterine growth, assessed indirectly through birthweight, is the key to survival of newborns in their first days of life and to health adequacy over the course of their life. Intrauterine growth restriction (IUGR) may lead to high neonatal morbidity and mortality. IUGR may also affect neurological and psychomotor development and the nutrition of the child, adolescent, and future mother (1-3). It is important to differentiate infants with actual IUGR (constitutionally small newborns) from those born outside of the ideal gestational age and weight. Low birthweight (LBW) is defined as the newborn weighing less than $2500 \mathrm{~g}$ at birth $(1,4)$. Small for gestational age (SGA) is defined by 
the birthweight of the newborn being below the $10^{\text {th }}$ percentile on standard curves. Preterm birth (PTB) is the term for birth before 37 weeks of gestation having been reached (5). LBW, SGA, or preterm newborns are also at high risk of perinatal death $(6,7)$, and they represent an important public health issue in high-income countries as well as in middle- and low-income nations $(4,6,7)$.

Standardized intrauterine growth curves according to the gestational age and sex can determine whether LBW has symmetrical or asymmetrical growth, which helps identify the etiopathogenesis of LBW (4). LBW may derive from: (i) symmetrical IUGR, which compromises all growth, including changes in head circumference growth, and has early onset with low ponderal index and usually intrinsic fetal etiology, or (ii) asymmetrical IUGR, with greater head circumference in relation to height and weight, late onset (usually in the third trimester of pregnancy), and low ponderal index, which is caused, in the vast majority of cases, by uterine placental insufficiency (8).

Newborns with asymmetrical IUGR are known as SGA. They are at risk of persistent hypoglycemia and may suffer worrisome short- and long-term neurological consequences (8). Symmetrical cases represent only $20 \%$ of the cases, while asymmetrical ones correspond to the other $80 \%$ (1).

It is often hard to differentiate among the causes of LBW because of the interaction of the two most common etiologies, i.e., PTB and IUGR. This differentiation is very important, given that an association between these two conditions poses a much higher risk of morbidity or mortality than do these risks separately (4, 7-9). In addition, LBW and SGA newborns have 10 - to 20 -fold higher mortality than do those with normal weight $(7,9)$.

Several studies have suggested that socioeconomic and demographic factors are strongly associated with LBW, SGA, and PTB among newborns. The main determinant socioeconomic factors (SEFs) for PTB and/or IUGR are extremes of maternal age (10-12), few years of schooling (13-15), low socioeconomic position (16-18), black ethnicity (19-23), and either not being married or living with a partner $(24,25)$. These factors cannot be isolated regarding the etiopathogenesis of those outcomes because they are interconnected in several ways. One example is with Afro-American adolescent mothers, who may have such other factors as being single, having less schooling (15, $18)$, and belonging to low-income families $(10,13,26)$, which may contribute to their newborns having higher odds of LBW, SGA, or PTB.

SEFs relating to social position and, above all, family income and schooling have been shown to be important risk factors and to have an inverse linear relation with the prevalence of LBW, SGA, and PTB $(16-18,26)$. There is a predominance of premature and LBW newborns among black women, in both developing and developed nations (5).

This systematic review was intended to identify if income, schooling, or ethnicity have any associations with LBW, SGA, or PTB.

\section{METHODS}

The study is a systematic review and was submitted to PROSPERO, which is an international register of prospective systematic reviews; it was approved under registration number CRD42016038919. The study followed the recommendations of the Preferred Reporting Items for Systematic Reviews and Meta-Analyses (PRISMA), in all steps of the PRISMA-P 2015 checklist (27).

The search was conducted in two online databases, PubMed and Literature in the Health Sciences in Latin America and the Caribbean (LILACS). The search covered the period between 1 January 1982 and 5 May 2016. The search strategy to identify studies included use, respectively, of Medical Subject Headings $(\mathrm{MeSH})$ and Health Sciences Descriptors (DeCS) terms. The descriptors used as MeSH and DeCS terms were: ("infant, premature" OR "infant, small for gestational age" OR "fetal growth retardation") AND ("maternal age" OR "socioeconomic factors" OR "ethnic groups"). The choice of these MeSH and DeCS terms involved other synonyms, including "fetal growth retardation" or "intrauterine growth retardation," which were important outcomes for following our objectives.

The first step was to identify all the references and then screen them for possible complete reading by searching for titles and/or abstracts containing the descriptors and/or the keywords "marital status," "poverty," or "education" (because of their close relationship with SEFs). The exclusion criteria were: (i) references relating to methods for measuring and/or identifying PTB, LBW, and SGA; (ii) outcomes relating to drug use, smoking alone, and such environmental factors as radiation, exposure to heavy metals, in vitro fertilization, multiple births, diets, supplements, and immigration; and (iii) risk factors relating to congenital malformations, genetic syndromes, or genetic factors that might lead to situations of congenital infections, maternal diseases, placental diseases, recurring miscarriages, stillbirths, or PTB. The inclusion criteria were that papers: (i) be published in Portuguese, English, or Spanish; (ii) be original or review papers; (iii) be the first paper published when belonging to the same study; (iv) describe more than one outcome relating to the socioeconomic/demographic risk factors chosen; and (v) show a Downs and Black (D\&B) score $\geq 12$ (28) (which is described below).

A protocol was defined for data extraction. The protocol included year of publication, country of the study, study design, sample size, study objectives, inclusion and exclusion criteria, control for confounding factors, and main results. Two researchers independently performed the selection process with the references and did the data extraction. The two researchers discussed any disagreements, and reached a final decision by consensus.

All selection stages were performed using EndNote software (http://www. endnote.com/). After the database search, duplicate papers were excluded. The inclusion and exclusion criteria were then applied, and references were selected for full reading. These were reviewed separately by two researchers using modified D\&B criteria (1998) (27). The D\&B questions relating to experimental studies were excluded, so the maximum score possible was 18 out of the 27 items of the original D\&B scale.

The D\&B checklist was developed and validated for methodological quality assessment of randomized and observational studies, for the domains of reporting, external validity, internal validity, confounding/selection bias, and power. Each question scored 1 when the answer was yes and 0 for no. Only one question, regarding the description of potential confounding factors, was scored differently: 2 for yes, 1 for partially, and 0 for no. 
The articles were classified as presenting a high chance of bias (0 to 5 points), average chance of bias (6 to 11 points), or a low chance of bias (12 to 18 points). Then, the articles with a low chance of bias were separated out to improve methodological quality, which was assessed in terms of the study design (goals, risks, outcome definition, outcome measurement, control for possible confounding factors, etc.), adequacy of the statistical analysis, and discussion of the study's limitations. Two independent reviewers scored the articles, and a third reviewer settled any disagreements.

\section{RESULTS}

Figure 1 shows the selection steps of this review.

This systematic review was carried out in an open manner in order to detect multiple studies that used income, maternal or family education, and ethnicity as the main socioeconomic and demographic determining factors in relation to at least two of the three main poor neonatal outcomes involving birthweight and PTB.

FIGURE 1. Flowchart of the selection steps for the systematic review of the associations that income, education, and ethnicity may have with birthweight and prematurity

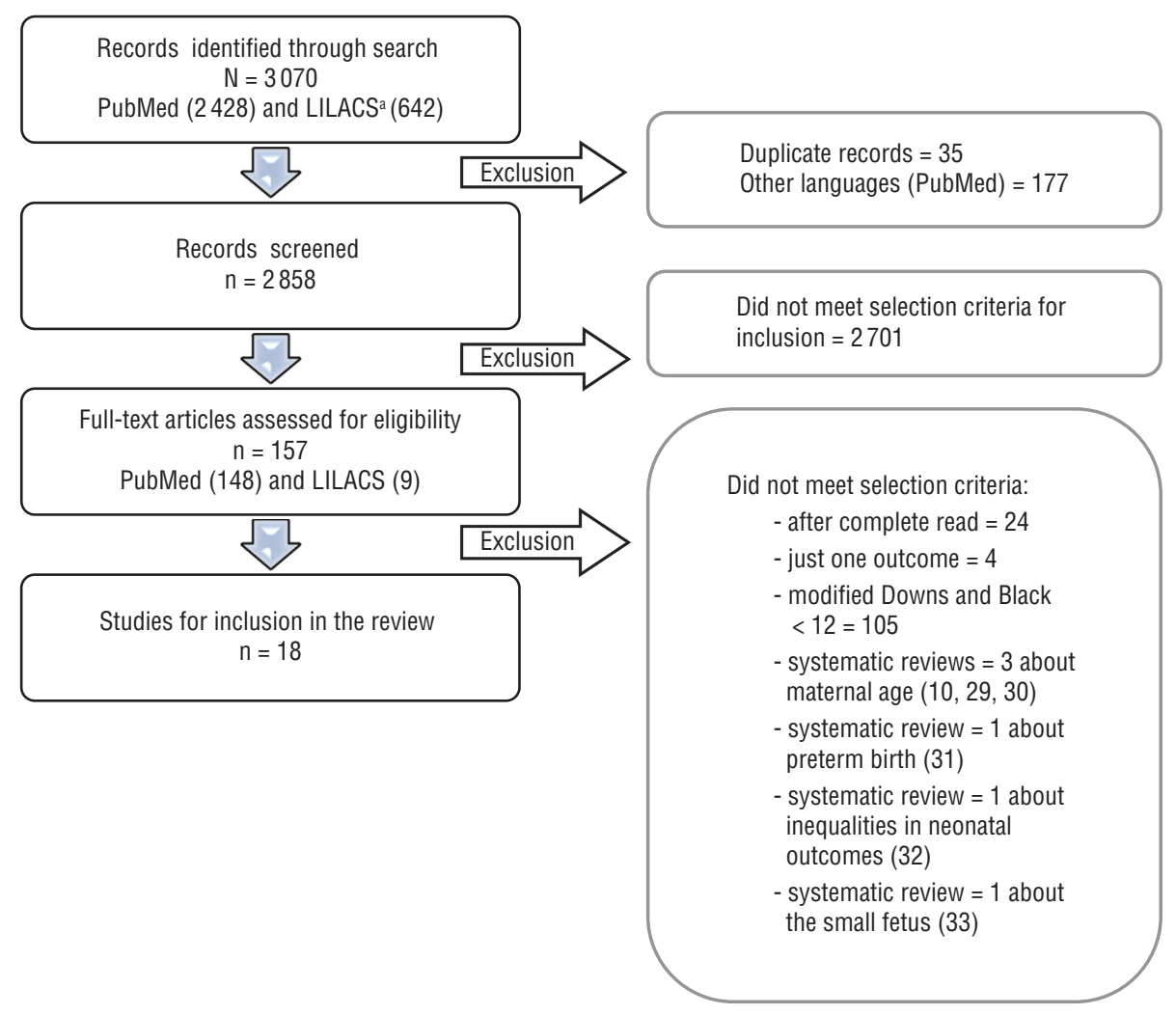

Source: Prepared by the authors.

${ }^{a}$ LILACS = Literature in the Health Sciences in Latin America and the Caribbean.
A total of 3070 references meeting the initial inclusion criteria were analyzed by reading the title and abstract. Then, 157 studies were selected and read by a pair of reviewers using the D\&B methodological criteria. From these readings, 18 studies in which the specific goal was to investigate neonatal outcomes relating to family or individual income, education, or ethnicity and that presented a low chance of bias (D\&B score $\geq 12$ ) were selected (Figure 1).

No specific review based on the main objectives was chosen for the present study. Six systematic review articles were found and excluded: three on maternal age $(10,29,30)$, one on disparities in PTB rate (31), one on inequalities in neonatal outcomes (32), and one on small fetus (33). This left a total of 18 articles selected for this review (Figure 1).

Of the 18 studies, 10 of them involved high-income countries, while 8 were in low-income countries and/or middleincome countries. One study (16) only scored 12 points, while all the others scored 14 or more points. Most of the studies used samples from birth cohorts

Duplicate records $=35$

Other languages $($ PubMed $)=177$

Did not meet selection criteria for inclusion $=2701$

id not meet selection criteria:

$<12=105$

systematic reviews $=3$ about

maternal age $(10,29,30$

-systematic review $=1$ about birth $(31)$

systematic review = 1 about

the small fetus (33) or national vital statistics reports, and had appropriate power to detect clinical effects. Four studies aimed to analyze LBW, SGA, and PTB at the same time (15, $16,20,26$ ).

Information from these 18 studies can be seen in Table 1. All of these studies reported prematurity as the main outcome; 12 of them also investigated SGA $(13,15-20,23,26,34-36) ; 11$ of them also explored LBW $(12,15,16,20-22,25,26$, $35,37,38$ ) (Table 1).

A total of 11 studies showed an association between PTB and at least one of the indicators studied; 9 studies did so for SGA and one or more indicators; and 7 studies did so for LBW and one or more indicators. Six studies $(13,18,26$, 34-36) analyzed more than one determinant. LBW was associated with low income, poverty, wealth indices, or socioeconomic level in 2 studies $(16,26)$; with education in 1 study (15); and with black ethnicity in 4 studies $(12,20,22$, 38). SGA was associated with being poor in 4 studies $(16-18,26)$; with education in 3 studies $(13,15,18)$; and with black skin color in 4 studies $(18-20,23)$. Regarding PTB, 2 studies $(16,18)$ found an association with low income; 4 studies $(13,15,18,26)$ with schooling; and 7 studies with black skin color $(12,18-20$, 22, 23, 38) (Table 1).

Some studies did not provide sufficient information to identify the effect measurements and confidence intervals (CIs) or their confounding factors in the final adjusted analysis. Effect measurements, such as the odds ratio (OR), relative risk (RR), and hazard ratio (HR) regarding final determinations of the influence of income, education, and/or ethnicity on the outcomes studied, are summarized in Table 2, and with complete data given in the supplementary material.

\section{Income or related factors as determinants}

An association between prematurity and income was observed in two studies: one from Brazil (16) and one from the United States of America (18). The vast majority of the studies did not find any such association (Table 1 and Table 2).

There was a lower chance that LBW would occur in situations of higher wealth or family income, especially in low-income countries $(16,26)$. In Indonesia, newborns showed adjusted odds ratios for LBW that were $32 \%$ and $44 \%$ higher if 
TABLE 1. Summary of the studies correlating family income, education, and ethnicity with low birthweight (LBW), small for gestational age (SGA), and/or preterm birth (PTB), including with score in the Downs and Black (D\&B) evaluation and the association (assoc.) with the outcome studied

\begin{tabular}{|c|c|c|c|c|c|c|c|}
\hline Determinant(s)/Study ${ }^{a}$ & Study design & Population characteristics & $\begin{array}{l}\text { Socioeconomic } \\
\text { factor(s) studied }\end{array}$ & $\begin{array}{l}\text { D\&B } \\
\text { score }\end{array}$ & $\begin{array}{l}\text { Assoc. with } \\
\text { LBW }\end{array}$ & $\begin{array}{l}\text { AssOC. } \\
\text { with SGA }\end{array}$ & $\begin{array}{l}\text { Assoc. with } \\
\text { PTB }\end{array}$ \\
\hline \multicolumn{8}{|l|}{ Income } \\
\hline Barros et al. (16), 2008, Brazil & Birth cohort & $\begin{array}{l}5914 \text { children (1982), } 5249 \text { (1993), } \\
\text { and } 4231 \text { (2004) }\end{array}$ & Income & 12 & Assoc. & Assoc. & Assoc. \\
\hline Joseph et al (17), 2007, Canada & Birth cohort & 76440 births from 1988 to 1995 & Income & 16 & $-b$ & Assoc. & No assoc. ${ }^{c}$ \\
\hline \multicolumn{8}{|l|}{ Education } \\
\hline Park et al. (15), 2013, Korea & Birth cohort & 7766065 births from 1995 to 2008 & $\begin{array}{l}\text { Paternal and } \\
\text { maternal } \\
\text { education }\end{array}$ & 17 & Assoc. & Assoc. & Assoc. \\
\hline Yunis et al. (37), 2003, Lebanon & Birth cohort & $\begin{array}{l}3372 \text { newborns from five National } \\
\text { Collaborative Perinatal Neonatal } \\
\text { Network centers from } 2000 \text { to } 2002 \text {. }\end{array}$ & Education & 14 & No assoc. & - & No assoc. ${ }^{\mathrm{c}}$ \\
\hline $\begin{array}{l}\text { Letamo \& Majelantle (25), 2001, } \\
\text { Botswana }\end{array}$ & Vital statistics & $\begin{array}{l}7265 \text { obstetric records from the } \\
\text { Botswana Obstetric Record from } \\
1990 \text { to } 1995\end{array}$ & Education & 15 & No assoc..$^{c}$ & - & No assoc. \\
\hline \multicolumn{8}{|l|}{ Ethnicity } \\
\hline Khalil et al. (19), 2013, England & $\begin{array}{l}\text { Retrospective } \\
\text { chart review }\end{array}$ & $\begin{array}{l}76158 \text { obstetric records included } \\
\text { in the study }\end{array}$ & Ethnicity & 15 & - & Assoc. & Assoc. \\
\hline Nyarko et al. (21), 2013, Brazil & $\begin{array}{l}\text { National survey } \\
(\text { ECLAMC })^{d}\end{array}$ & $\begin{array}{l}8949 \text { singleton live births from } \\
1995 \text { to } 2009\end{array}$ & Ethnicity & 14 & No assoc. & - & No assoc. \\
\hline $\begin{array}{l}\text { Nabukera et al. (20), 2009, } \\
\text { United States }\end{array}$ & Birth cohort & $\begin{array}{l}239930 \text { singleton sibling pairs (whites/ } \\
\text { African-Americans in } 1978 \text { to 1997) }\end{array}$ & Ethnicity & 16 & Assoc. & Assoc. & Assoc. \\
\hline Paul et al. (22), 2008, United States. & $\begin{array}{l}\text { Retrospective } \\
\text { case-control }\end{array}$ & $\begin{array}{l}44105 \text { black newborns, } \geq 35 \text { w of } \\
\text { gestational age and } 88210 \text { white mother/ } \\
\text { baby pairs from } 1998 \text { to } 2002\end{array}$ & Ethnicity & 16 & Assoc. & - & Assoc. \\
\hline $\begin{array}{l}\text { Ehrenthal et al. (38), 2007, } \\
\text { United States }\end{array}$ & Birth cohort & 18624 consecutive births & Ethnicity & 15 & Assoc. & - & Assoc. \\
\hline $\begin{array}{l}\text { Simon et al. (23), 2006, } \\
\text { United States }\end{array}$ & Vital statistics & $\begin{array}{l}\text { Vital records of African-American } \\
\text { (61 849) and white (203 698) } \\
\text { infants born from } 1989 \text { to } 1991\end{array}$ & Ethnicity & 17 & - & Assoc. & Assoc. \\
\hline $\begin{array}{l}\text { DuPlessis et al. (12), 1997, } \\
\text { United States }\end{array}$ & Vital statistics & 54447 birth from 1980 to 1987 & Ethnicity & 15 & Assoc. & - & Assoc. \\
\hline \multicolumn{8}{|l|}{ More than one determinant } \\
\hline Mortensen (13), 2013, Denmark & Birth cohort & $\begin{array}{l}471215 \text { observations of children born } \\
\text { between } 1996 \text { and } 2007\end{array}$ & $\begin{array}{l}\text { Income } \\
\text { Education }\end{array}$ & 14 & - & $\begin{array}{l}\text { No assoc. } \\
\text { Assoc. }\end{array}$ & $\begin{array}{l}\text { No assoc. } \\
\text { Assoc. }\end{array}$ \\
\hline $\begin{array}{l}\text { Sebayang et al. (26), } 2012 \text {, } \\
\text { Indonesia }\end{array}$ & Birth cohort & $\begin{array}{l}14040 \text { LBW births and } 13498 \text { PTBs } \\
\text { from } 2001 \text { to } 2004\end{array}$ & $\begin{array}{l}\text { Income } \\
\text { Education }\end{array}$ & 14 & $\begin{array}{l}\text { Assoc. } \\
\text { No assoc. }\end{array}$ & $\begin{array}{l}\text { Assoc. } \\
\text { No assoc. }\end{array}$ & $\begin{array}{l}\text { No assoc. } \\
\text { Assoc. }\end{array}$ \\
\hline Magadi et al. (34), 2001, Kenya & $\begin{array}{l}\text { Vital statistics and } \\
\text { national survey }\end{array}$ & 5295 births & $\begin{array}{l}\text { Socioeconomic } \\
\text { position } \\
\text { Education }\end{array}$ & 15 & - & $\begin{array}{l}\text { No assoc. } \\
\text { No assoc. }\end{array}$ & $\begin{array}{l}\text { No assoc. } \\
\text { No assoc. }\end{array}$ \\
\hline Savitz et al. (18), 2004, United States & Birth cohort & $\begin{array}{l}2052 \text { neonates of African-American and } \\
\text { white mothers from } 1996 \text { to } 2000\end{array}$ & $\begin{array}{l}\text { Ethnicity, } \\
\text { poverty, and } \\
\text { education }\end{array}$ & 14 & - & Assoc. & Assoc. \\
\hline $\begin{array}{l}\text { Tuntiseranee et al. (35), 1999, } \\
\text { Thailand }\end{array}$ & Birth cohort & 1797 births from 1994 to 1995 & $\begin{array}{l}\text { Income or } \\
\text { socioeconomic } \\
\text { position }\end{array}$ & 14 & No assoc. ${ }^{c}$ & No assoc. & No assoc. \\
\hline Arbuckle et al. (36), 1989, Canada & $\begin{array}{l}\text { Population-based } \\
\text { study }\end{array}$ & 806 singleton births from 1970 to 1973 & $\begin{array}{l}\text { Education } \\
\text { Income } \\
\text { Education }\end{array}$ & 15 & $\begin{array}{l}\text { No assoc. } \\
- \\
-\end{array}$ & $\begin{array}{l}\text { No assoc. } \\
\text { No assoc. } \\
\text { No assoc. }\end{array}$ & $\begin{array}{l}\text { No assoc. } \\
\text { No assoc. }{ }^{c} \\
\text { No assoc. }{ }^{c}\end{array}$ \\
\hline
\end{tabular}

Source: Table prepared by authors from their study results.

a The information for each study includes its lead author or its two authors, the References number, the year of publication, and the country investigated.

b - = not shown by the study's authors.

${ }^{\mathrm{c}}$ after adjustment.

${ }^{\mathrm{d}}$ ECLAMC $=$ Latin American Collaborative Study of Congenital Malformations. 
TABLE 2. Summary data comparison of studies on low birthweight (LBW), small for gestational age (SGA), and preterm births (PTBs), with association measurements with the odds ratio (OR), adjusted odds ratio (AOR), relative risk (RR), hazard ratio (HR), and adjusted hazard ratio (AHR) and their respective confidence intervals (Cls) relating to family income, education, and/or ethnicity

\begin{tabular}{|c|c|c|c|c|c|c|}
\hline Determinant(s)/Study ${ }^{a}$ & $\begin{array}{c}\text { LBW } \\
\text { OR }(95 \% \mathrm{Cl})\end{array}$ & $\begin{array}{c}\text { LBW } \\
\text { AOR }(95 \% \mathrm{Cl})\end{array}$ & $\begin{array}{c}\text { SGA } \\
\text { OR }(95 \% \mathrm{Cl})\end{array}$ & $\begin{array}{c}\text { SGA } \\
\text { AOR }(95 \% \mathrm{Cl})\end{array}$ & $\begin{array}{c}\text { PTB } \\
\text { OR }(95 \% \mathrm{Cl})\end{array}$ & $\begin{array}{c}\text { PTB } \\
\text { AOR }(95 \% \mathrm{Cl})\end{array}$ \\
\hline \multicolumn{7}{|l|}{ Joseph et al. (17), 2007, Canada } \\
\hline The richest & $-\mathrm{b}$ & - & 1.00 & 1.00 & 1.00 & 1.00 \\
\hline The poorest & & & $1.81(1.66-1.97)^{c}$ & $1.34(1.18-1.74)^{c}$ & $1.20(1.06-1.35)^{c}$ & $1.12(0.94-1.35)$ \\
\hline \multicolumn{7}{|l|}{ Education } \\
\hline \multicolumn{7}{|l|}{ Paternal education } \\
\hline$\geq$ University & - & 1.00 & - & 1.00 & - & 1.00 \\
\hline$\leq$ Middle school & & $1.56(1.54-1.59)$ & & $1.68(1.64-1.71)$ & & $1.28(1.26-1.30)$ \\
\hline \multicolumn{7}{|l|}{ Maternal education } \\
\hline$\geq$ University & - & 1.00 & - & 1.00 & - & 1.00 \\
\hline$\leq$ Middle school & & $1.62(1.59-1.65)$ & & $1.70(1.66-1.74)$ & & $1.32(1.30-1.35)$ \\
\hline No formal education & & & & & & $0.62(0.32-1.21)$ \\
\hline \multicolumn{7}{|l|}{$\begin{array}{l}\text { Letamo \& Majelantle (25), } \\
\text { 2001, Botswana }\end{array}$} \\
\hline \multicolumn{7}{|l|}{ Education } \\
\hline Secondary + & 1.00 & 1.00 & - & - & 1.00 & 1.00 \\
\hline No education & 1.4184 & 1.4149 & & & 0.8204 & 1.0156 \\
\hline \multicolumn{7}{|l|}{ Ethnicity } \\
\hline \multicolumn{7}{|l|}{ Khalil et al. (19), 2013, England } \\
\hline \multicolumn{7}{|l|}{ Maternal racial origin } \\
\hline Caucasian & - & - & - & 1.00 & - & 1.00 \\
\hline Afro-Caribbean & & & & $2.35(2.16-2.57)^{\mathrm{c}, \mathrm{d}}$ & & $\begin{array}{l}1.94(1.63-2.32)^{c, e} \\
2.78(2.22-3.49)^{c, f}\end{array}$ \\
\hline \multicolumn{7}{|l|}{ Ethnic origin } \\
\hline White American & - & 1.00 & - & 1.00 & - & 1.00 \\
\hline African-American & & $2.35(2.20-2.51)$ & & $1.95(1.84-2.07)$ & & $1.92(1.82-2.03)$ \\
\hline \multicolumn{7}{|l|}{ Paul et al. (22), 2008, United States } \\
\hline \multicolumn{7}{|l|}{ Ethnic origin } \\
\hline Non-Hispanic whites & 1.00 & - & - & - & 1.00 & - \\
\hline Non-Hispanic blacks & $2.09(1.96-2.23)$ & & & & $1.80(1.71-1.90)$ & \\
\hline \multicolumn{7}{|l|}{$\begin{array}{l}\text { Ehrenthal et al. (38), 2007, } \\
\text { United States }\end{array}$} \\
\hline \multicolumn{7}{|l|}{ Ethnic origin } \\
\hline White American & 1.00 & 1.00 & - & - & 1.00 & 1.00 \\
\hline Black American & $2.2(2.0-2.5)$ & $1.9(1.6-2.1)$ & & & $1.6(1.4-1.8)$ & $1.3(1.2-1.5)$ \\
\hline $\begin{array}{l}\text { Simon et al. (23), 2006, } \\
\text { United States }\end{array}$ & & & & & & \\
\hline Ethnic origin & & & & & & \\
\hline
\end{tabular}


TABLE 2. (Continued)

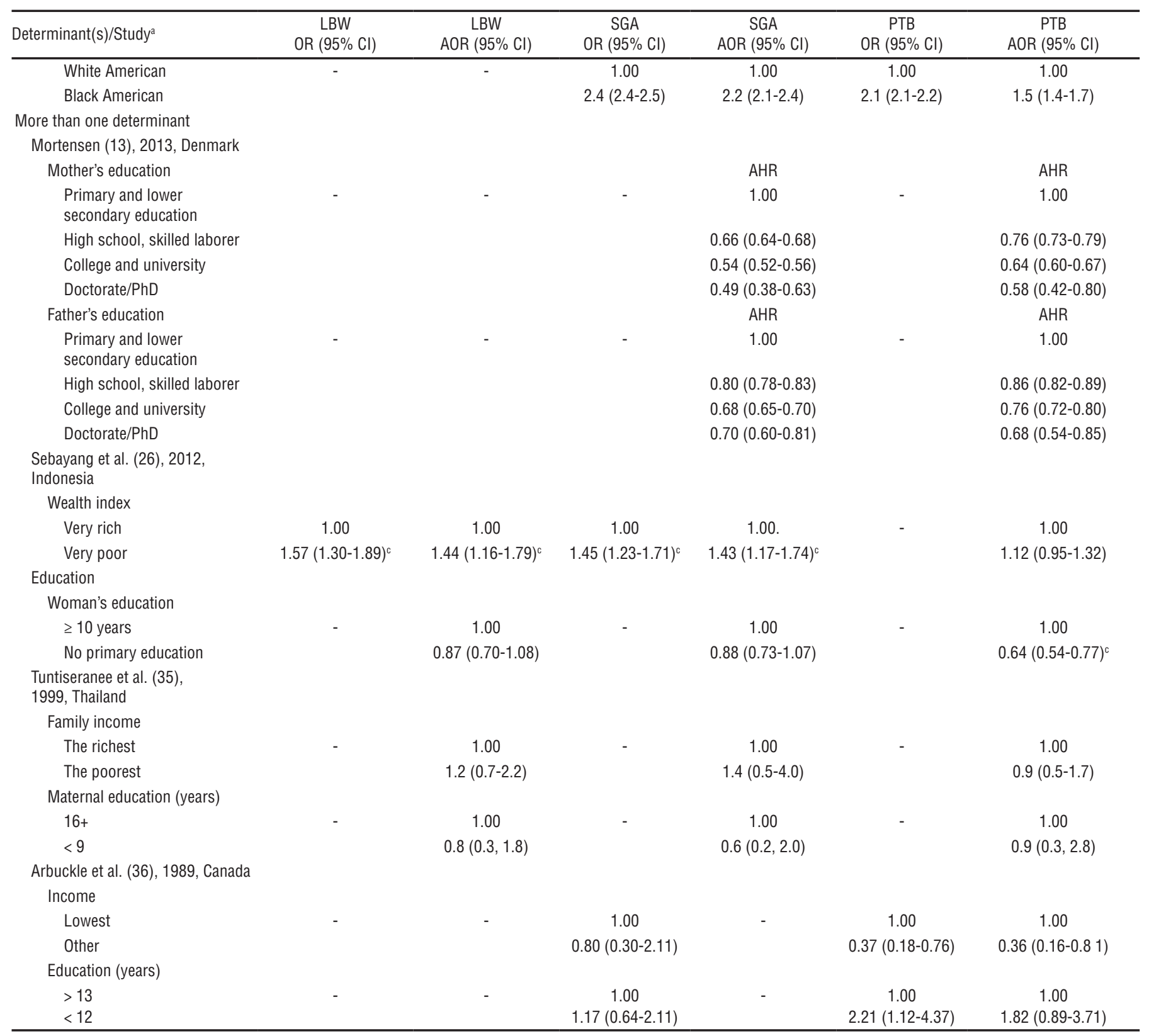

Source: Table prepared by authors from their study results, for published data.

${ }^{a}$ The information for each study includes its lead author or its two authors, the References number, the year of publication, and the country researched.

${ }^{b}{ }_{-}=$not shown by the study's authors.

${ }^{\mathrm{c}} p<0.01$.

dSGA (birthweight $<5^{\text {th }}$ percentile).

${ }^{e}$ Spontaneous delivery.

${ }^{\dagger}$ latrogenic delivery.

${ }^{9} p<0.05$.

they were from, respectively, poor or very poor families than if they were from wealthy families (26) (supplementary material). In Brazil, a study using income quintiles in the 1980s and 1990s showed a downward trend for LBW that was proportional to the increase in income, with risks of LBW in lower quintiles that were
2.8 and 2.4 times higher than in higher quintiles (16). Another study, in Thailand, showed a significant association between higher income and higher birthweight, which was not maintained after adjusted analysis (35) (Table 1).

A higher risk of SGA infants in underprivileged populations was found in
Brazil (16), Canada (17), and Indonesia (26) (Table 2). Also in Canada (17), there was a significant association between the occurrence of SGA and the lowest income quintile, which remained after the statistical analysis had been adjusted for other demographic and socioeconomic factors (Table 2). 


\section{Maternal or family education as determinants}

Only one study reported an association of maternal and paternal education with the three outcomes (15), while one study associated these factors with SGA and PTB (13). In situations of low paternal education and low maternal education, respectively, Park et al. (15) found adjusted odds ratios (AORs) for LBW that were $56 \%$ and $62 \%$ higher, for SGA that were $68 \%$ and $70 \%$ higher, and for PTB that were $28 \%$ and $32 \%$ higher. In Indonesia, Sebayang et al. (26) found that women with 10 or more years of education were less likely to have a premature baby $(\mathrm{OR}=0.64$; 95\% CI: 0.54-0.77, $p<$ $0.0001)$ than were those without basic education (Table 2).

Mortensen et al. (13) found that the adjusted hazard ratio decreased as maternal or paternal education increased, for both SGA and PTB. However, other studies did not show any association between low education and one or more of the outcomes studied: for LBW (26, 35), SGA $(26,34-36)$, or PTB $(25,34-36)$ (Table 2).

\section{Ethnicity as a determinant}

One study demonstrated an association of maternal ethnicity with the three outcomes (20). Three studies associated this determinant with LBW and PTB (12, $22,38)$. Another three studies demonstrated an association of maternal ethnicity with SGA and PTB $(18,19,23)$. In just one study, black skin color was not associated with LBW or PTB (21). These studies were conducted in high-income countries, except for the one carried out in Brazil (21).

Ehrenthal et al. (38) showed that there was a higher prevalence of LBW and extreme prematurity among mothers with black ethnicity. This risk was almost three times higher than the risk presented by white mothers. This was similar to the findings of Paul et al. (22) and DuPlessis et al. (12), who found that the risk that newborns would present LBW and PTB was about twice as high among black mothers.

The strongest association was between black ethnicity and prematurity, followed by SGA and LBW. However, most studies did not find any association of socioeconomic or educational determinants with the outcomes of interest.

\section{DISCUSSION}

Among the 18 studies selected, income was investigated in similar numbers of studies in high-income versus low- and middle-income countries. However, education levels and black ethnicity differed from this pattern, in that education was investigated more in low-/middle-income countries, while black ethnicity was investigated more in high-income countries. Our review on the association between socioeconomic and demographic determinants and unfavorable neonatal outcomes showed that income and education were not the most important contributory factors towards LBW or SGA or PTB. However, black ethnicity was highly associated with all three outcomes, and the largest association was between PTB and black ethnicity, especially in high-income countries.

There are many studies in the literature with interesting proposals for socioeconomic and demographic risk factors for LBW, SGA, or PTB among newborns. A higher number of studies have focused on such ethnic factors as black skin color (19-23), and a smaller number have concentrated on specific SEFs, such as income $(16,18,26,35)$ and education $(13,15,18)$.

Women of black ethnicity account for the highest percentage of underweight births (9.4\%) (4) and also for higher neonatal mortality rates (3). The association of black skin color with LBW has been clearly demonstrated in developed countries $(12,20,22,38)$, along with the greater likelihood of prematurity $(12,18-20,22$, $23,38)$ and SGA births $(18-20,23)$, regardless of whether these women live in highor low-income countries. In a study on racial disparities in the United States, the correlation between black skin color and birth with IUGR was not a result of the mothers' ethnicity, but was the sum of other socioeconomic-demographic factors involved in the social context within which the individual lived (39).

In a study done in seven states of Brazil, Nyarko et al. (21) found a higher prevalence of LBW and prematurity among families of black skin color in a population of 8949 single births, when using multivariate analysis to consider demographic, socioeconomic, health care, and geographical effects. However, after adjustment for other SEFs, there was a reduction of the association of this skin-color determinant with LBW. This demonstrates the need for joint assessment of the effects of maternal education, maternal health, and geographical location, because of the differing physical and socioeconomic environments in Brazil (21).

Another determinant of individuals' socioeconomic position is income, which is one of the most important SEFs relating to social exclusion and, consequently, health inequalities (32). It may be a factor that can produce changes in health from fetus to adolescence and adult life, which may lead to women having nutritional or metabolic disorders that may affect the outcome of any future pregnancies. This could then result in neonatal and childhood morbidities with a significant later impact on individual human capital $(7,9)$.

The lowest income group, independent of the country's currency, has been one of the major SEFs involved in LBW. However, there are a number of factors that overlap in this context, such as poverty associated with inadequate maternal health or nutrition since childhood and/or adolescence. The maintenance of these socioeconomic factors in pregnancy generates injuries in fetal growth, with repercussions on the final birthweight. Nevertheless, after controlling for the effect of other factors, it has been seen that there is an increased risk of LBW and SGA among low-income families, with higher morbidity/mortality during childhood and even recurrence of LBW in future pregnancies $(2,17)$.

Savitz et al. (18) found that poverty was associated with a higher risk of premature birth among African-American mothers with $\geq 12$ years of schooling (RR 1.6; 95\% CI: 1.1-2.2), as well as a higher risk of SGA (RR 1.7; 95\% CI: 1.1-2.7) among white mothers. However, white mothers with low education and income below the poverty line also presented a higher risk of PTB (RR 1.7; 95\% CI: 1.1-2.7). Those researchers also encouraged discussion of the importance of a careful assessment of socioeconomic indicators among ethnic subgroups, given the joint effect of these factors.

Low parental education had a great effect on the three outcomes in a Korean study, and with significant interactions with parental employment. The work situation of parents with higher education levels had minimal effects on LBW, SGA, or PTB. However, parents with lower education levels or who were 
unemployed or performed manual labor were the group that was most vulnerable to an adverse birth, thus again confirming the interaction of these factors (15).

Few studies in this review showed any association of income or education with PTB, regardless of where the investigations were conducted. In recent decades, as the number of PTBs has tended to increase, newborn survival and quality-of-life indices in low-income countries have significantly differed from the patterns in high-income countries $(5,6)$.

Regarding ethnicity, large numbers of studies have shown that maternal black skin color is a risk factor for PTB and LBW $(12,20,22,38)$; a few studies have found that is also true for SGA (18-20, 23). Low socioeconomic status of black women could lead to difficult access to health care $(5,39)$. Given that, with pregnant black women, the early identification of widely known risk factors $(5,39)$ and active search for these cases for close follow-up is advisable.

Various factors might help reduce high PTB rates. These include access to an appropriate number of perinatal consultations, the attitude of health care professionals and institutions involved in antenatal care, early diagnosis of gestational age, diagnosis of specific pregnancy diseases, and precise indication for surgical procedures $(7,40,41)$.

A major positive point in this review was evaluating three important factors associated with inequality in prenatal care. Income and education were not associated with inadequate childbirth outcomes, except for black women, particularly with PTB. However, SEFs still remain risk factors for inequality in antenatal care services $(16-18,26,40)$. Even in the reports that jointly investigated these factors, the vast majority of the studies found no association with inappropriate neonatal outcomes $(26,34-36)$. It is important to highlight the difficulty of evaluating the interaction of these demographic and socioeconomic features, as well as black ethnicity and other circumstances that could be involved in inequity in the support for pregnant women and for childbirth services.

The shortcomings in this review may relate to the statistical analyses in some of the studies included. Several studies assessed the effects of income, education, and ethnicity without exclusion of other socioeconomic and demographic factors that might have acted as confounding factors in the correlations between these determinants and the outcomes. In addition, the heterogeneity of the studies, especially the income studies, and the difficulty of subgroup analysis in the primary studies contributed to limitations in the review. This prevented us from proceeding with the initial intention to do a meta-analysis, given the difficulty in comparing the effect measurements informed by each study.

The more restrictive inclusion criteria that we used to reduce bias may have limited the utilization of studies conducted in low- and middle-income countries. This could explain why the results found in this review differed from what was observed in original source articles from Barros et al. (16) in Brazil, Park et al. (15) in Korea, and Sebayang et al. (21) in Indonesia, in which income or education was associated with inadequate delivery outcomes. Moreover, few studies used hierarchical analysis on the possible confounding factors. It would be difficult to conduct an analysis with greater accuracy in order to identify other confounding, mediation, or interaction factors that would contribute towards the final result regarding the birth outcomes studied. Nonetheless, the articles that we selected presented results in line with the literature.

Further studies should be conducted on these three outcomes for newborns. However, this research should apply different methodologies and include possible confounding factors, in order to detail the magnitude of the role of each socioeconomic and demographic factor. Such new research might lead to effective public policies for reducing inequalities relating to perinatal health and human capital.

Funding. Provided by the Coordenação de Aperfeiçoamento de Pessoal de Nível Superior (CAPES).

Conflicts of interest. The authors declare no conflicts of interest.

Disclaimer. The author holds sole responsibility for the views expressed in the manuscript, which may not necessarily reflect the opinion or policy of the RPSP/PAJPH or PAHO.

\section{REFERENCES}

1. Mayer C, Joseph KS. Fetal growth: a review of terms, concepts and issues relevant to obstetrics. Ultrasound Obstet Gynecol. 2013;41(2):136-45.

2. Uauy R, Corvalan C, Casanello P, Kuzanovic J. Intervention strategies for preventing low birthweight in developing countries: importance of considering multiple interactive factors. Nestle Nutr Inst Workshop Ser. 2013;74:31-52.

3. You D, Hug L, Chen Y, Wardlaw T, Newby H. Levels \& trends in child mortality. Report 2014. New York: UNICEF; 2014.

4. Kramer MS. Born too small or too soon. Lancet Glob Health. 2013;1(1):e7-8.

5. March of Dimes; Partnership for Maternal, Newborn \& Child Health; Save the Children; World Health Organization.
Born too soon: the global action report on preterm birth. Geneva: WHO; 2012.

6. Blencowe H, Cousens S, Chou D, Oestergaard M, Say L, Moller AB, et al. Born too soon: the global epidemiology of 15 million preterm births. Reprod Health. 2013;10(Suppl 1):S2.

7. Lawn JE, Blencowe H, Oza S, You D, Lee AC, Waiswa P, et al. Every newborn: progress, priorities, and potential beyond survival. Lancet. 2014;384(9938): 189-205.

8. Bhatia J, Gates A. Immediate metabolic consequences of intrauterine growth restriction and low birthweight. Nestle Nutr Inst Workshop Ser. 2013;74:157-64.

9. Blencowe H, Cousens S, Oestergaard MZ, Chou D, Moller AB, Narwal R, et al. National, regional, and worldwide estimates of preterm birth rates in the year 2010 with time trends since 1990 for selected countries: a systematic analysis and implications. Lancet. 2012;379(9832):2162-72.

10. Newburn-Cook CV, Onyskiw JE. Is older maternal age a risk factor for preterm birth and fetal growth restriction? A systematic review. Health Care Women Int. 2005;26(9):852-75.

11. Khalil A, Syngelaki A, Maiz N, Zinevich Y, Nicolaides KH. Maternal age and adverse pregnancy outcome: a cohort study. Ultrasound Obstet Gynecol. 2013;42(6):634-43.

12. DuPlessis HM, Bell R, Richards $T$. Adolescent pregnancy: understanding 
the impact of age and race on outcomes. J Adolesc Health. 1997;20(3):187-97.

13. Mortensen LH. Socioeconomic inequality in birth weight and gestational age in Denmark 1996-2007: using a family-based approach to explore alternative explanations. Soc Sci Med. 2013;76(1):1-7.

14. Heaman M, Kingston D, Chalmers B, Sauve $\mathrm{R}$, Lee L, Young D. Risk factors for preterm birth and small-for-gestational-age births among Canadian women. Paediatr Perinat Epidemiol. 2013;27(1):54-61.

15. Park MJ, Son M, Kim YJ, Paek D. Social inequality in birth outcomes in Korea, 1995-2008. J Korean Med Sci. 2013;28(1):25-35.

16. Barros FC, Victora CG, Matijasevich A, Santos IS, Horta BL, Silveira MF, et al. Preterm births, low birth weight, and intrauterine growth restriction in three birth cohorts in Southern Brazil: 1982, 1993 and 2004. Cad Saude Publica. 2008;24 Suppl 3:S390-8.

17. Joseph KS, Liston RM, Dodds L, Dahlgren $\mathrm{L}$, Allen AC. Socioeconomic status and perinatal outcomes in a setting with universal access to essential health care services. CMAJ. 2007;177(6):583-90.

18. Savitz DA, Kaufman JS, Dole N, Siega-Riz AM, Thorp JM, Jr., Kaczor DT. Poverty, education, race, and pregnancy outcome. Ethn Dis. 2004;14(3):322-9.

19. Khalil A, Rezende J, Akolekar R, Syngelaki A, Nicolaides KH. Maternal racial origin and adverse pregnancy outcome: a cohort study. Ultrasound Obstet Gynecol. 2013;41(3):278-85.

20. Nabukera SK, Wingate MS, Owen J, Salihu HM, Swaminathan S, Alexander GR, et al. Racial disparities in perinatal outcomes and pregnancy spacing among women delaying initiation of childbearing. Matern Child Health J. 2009;13(1):81-9.

21. Nyarko KA, Lopez-Camelo J, Castilla EE, Wehby GL. Explaining racial disparities in infant health in Brazil. Am J Public Health. 2013;103(9):1675-84.

22. Paul IM, Lehman EB, Suliman AK, Hillemeier MM. Perinatal disparities for black mothers and their newborns. Matern Child Health J. 2008;12(4):452-60.

23. Simon DM, Vyas S, Prachand NG, David RJ, Collins JW, Jr. Relation of maternal low birth weight to infant growth retardation and prematurity. Matern Child Health J. 2006;10(4):321-7.

24. Raatikainen K, Heiskanen N, Heinonen S. Marriage still protects pregnancy. BJOG. 2005;112(10):1411-6.

25. Letamo G, Majelantle RG. Factors influencing low birth weight and prematurity in Botswana. J Biosoc Sci. 2001;33(3):391-403.

26. Sebayang SK, Dibley MJ, Kelly PJ, Shankar $\mathrm{AV}$, Shankar AH. Determinants of low birthweight, small-for-gestational-age and preterm birth in Lombok, Indonesia: analyses of the birthweight cohort of the SUMMIT trial. Trop Med Int Health. 2012;17(8):938-50.

27. Moher D, Shamseer L, Clarke M, Ghersi D, Liberati A, Petticrew M, et al. Preferred reporting items for systematic review and meta-analysis protocols (PRISMA-P) 2015 statement. Syst Rev. 2015;4:1.

28. Downs SH, Black N. The feasibility of creating a checklist for the assessment of the methodological quality both of randomised and non-randomised studies of health care interventions. J Epidemiol Community Health. 1998;52(6):377-84.

29. Haaga JG. How are young maternal age and primiparity related to infant health? Malays J Reprod Health. 1989;7(1):27-40.

30. Cunnington AJ. What's so bad about teenage pregnancy? J Fam Plann Reprod Health Care. 2001;27(1):36-41.

31. Delnord M, Blondel B, Zeitlin J. What contributes to disparities in the preterm birth rate in European countries? Curr Opin Obstet Gynecol. 2015;27(2):133-42.

32. Kramer MS, Seguin L, Lydon J, Goulet L. Socio-economic disparities in pregnancy outcome: why do the poor fare so poorly? Paediatr Perinat Epidemiol. 2000;14(3):194-210.

33. Tambyraja RL, Ratnam SS. The small fetus: growth-retarded and preterm. Clin Obstet Gynaecol. 1982;9(3):517-37.
34. Magadi M, Madise N, Diamond I Factors associated with unfavourable birth outcomes in Kenya. J Biosoc Sci. 2001;33(2):199-225.

35. TuntiseraneeP, OlsenJ,Chongsuvivatwong $\mathrm{V}$, Limbutara S. Socioeconomic and work related determinants of pregnancy outcome in southern Thailand. J Epidemiol Community Health. 1999;53(10):624-9.

36. Arbuckle TE, Sherman GJ. Comparison of the risk factors for pre-term delivery and intrauterine growth retardation. Paediatr Perinat Epidemiol. 1989;3(2):115-29.

37. Yunis $K$, Beydoun $H$, Khogali $M$, Alameh M, Tamim H. Low socioeconomic status and neonatal outcomes in an urban population in a developing country. J Matern Fetal Neonatal Med. 2003;14(5):338-43.

38. Ehrenthal DB, Jurkovitz C, Hoffman M, Kroelinger C, Weintraub W. A population study of the contribution of medical comorbidity to the risk of prematurity in blacks. Am J Obstet Gynecol 2007;197(4):409.e1-6.

39. Kramer MS, Ananth CV, Platt RW, Joseph KS. US Black vs White disparities in foetal growth: physiological or pathological? Int J Epidemiol. 2006;35(5):1187-95.

40. Requejo J, Merialdi M, Althabe F, Keller M, Katz J, Menon R. Born too soon: care during pregnancy and childbirth to reduce preterm deliveries and improve health outcomes of the preterm baby. Reprod Health. 2013;10(Suppl 1):S4.

41. Lawn JE, Kinney MV, Belizan JM, Mason EM, McDougall L, Larson J, et al. Born too soon: accelerating actions for prevention and care of 15 million newborns born too soon. Reproductive Health. 2013;10(Suppl 1):S6

Manuscript received on 4 August 2017. Revised version accepted for publication on 3 January 2018. 
RESUMEN Objetivos. Encontrar evidencia de que los ingresos, la educación o la etnicidad podrían estar asociados con el peso bajo al nacer, el peso bajo para la edad gestacional o el nacimiento prematuro.

¿Cuán estrechas son las asociaciones de los

ingresos, la educación y la etnicidad con el peso al nacer y la prematuridad?

Palabras clave Renta; educación; grupos étnicos; retardo del crecimiento fetal; recién nacido prematuro.
Métodos. Se realizó una revisión sistemática mediante búsquedas en dos bases de datos en línea, PubMed y LILACS (Literature in the Health Sciences in Latin America and the Caribbean). Las búsquedas abarcaron los materiales publicados entre el 1 de enero de 1982 y el 5 de mayo del 2016. Los términos de búsqueda usados fueron ("infant, premature" $\mathrm{O}$ "infant, small for gestational age" $\mathrm{O}$ "fetal growth retardation") ["lactante, prematuro" $\mathrm{O}$ "lactante, pequeño para edad gestacional" $\mathrm{O}$ "retraso del crecimiento fetal"] Y ("socioeconomic factors" O "ethnic group") ["factores socioeconómicos" O "grupos étnicos" O "edad materna"].

Resultados. Se analizó un total de 3070 referencias que satisficieron los criterios de selección iniciales y se leyeron íntegramente 157 estudios pertinentes. Ubicamos 18 estudios que investigaron las asociaciones entre los ingresos, la educación o la etnicidad de la familia o la madre y el peso bajo al nacer, el peso bajo para la edad gestacional o el nacimiento prematuro. De estos 18 estudios, 10 fueron en países de ingresos altos y 8 en países de ingresos medianos o bajos. Se encontró más evidencia con respecto a la asociación entre la etnicidad y los tres resultados estudiados, en particular para la prematuridad en los hijos de mujeres de raza negra. Fue poca la evidencia respecto de la asociación entre los ingresos o la educación de la madre o la familia y cualquiera de los tres resultados.

Conclusiones. Los ingresos y la educación no fueron determinantes para el peso bajo al nacer o el peso bajo para la edad gestacional. Sin embargo, la etnicidad negra mostró una asociación estrecha con los tres resultados, especialmente con la prematuridad.

RESUMO Objetivos. Identificar evidências de que renda, escolaridade ou grupo étnico poderiam estar associados ao baixo peso ao nascer, recém-nascido pequeno para a idade gestacional ou prematuridade.

Associação de renda, escolaridade e grupo étnico com peso ao nascimento e prematuridade: qual é a proximidade entre eles?

Métodos. Um estudo de revisão sistemática foi realizado fazendo-se buscas em duas bases de dados online, PubMed e Literatura Latino-Americana e do Caribe em Ciências da Saúde (LILACS). As buscas abrangeram os materiais publicados entre $1^{\circ}$ de janeiro de 1982 e 5 de maio de 2016. Os termos de busca usados foram: ("infant, premature" OR "infant, small for gestational age" OR "fetal growth retardation") [("recém-nascido, prematuro" OU "recém-nascido, pequeno para idade gestacional" OU "retardo do crescimento fetal")] E ("socioeconomic factors" OR "ethnic groups" OR "maternal age") [("fatores socioeconômicos" OU "grupos étnicos" OU "idade materna")].

Resultados. Todas as 3.070 referências que satisfizeram os critérios iniciais de seleção foram analisadas e 157 estudos relevantes foram lidos na íntegra. Foram identificados 18 estudos que investigaram a associação entre renda familiar ou materna, escolaridade ou grupo étnico com baixo peso ao nascer, recém-nascido pequeno para a idade gestacional ou prematuridade. Dentre os 18 estudos, 10 foram conduzidos em países de alta renda e 8 em países de baixa e média renda. Um volume maior de evidências foi observado para a associação entre grupo étnico e os três desfechos estudados, sobretudo prematuridade em filhos de mulheres negras. Poucas evidências foram encontradas para a associação entre renda familiar/materna ou escolaridade e qualquer um dos três desfechos.

Conclusões. Renda e escolaridade não foram determinantes do baixo peso ao nascer, recém-nascido pequeno para a idade gestacional e prematuridade. Porém, o grupo étnico negro teve uma forte associação com os três desfechos, sobretudo com prematuridade.

Palavras-chave

Renda; educação; grupos étnicos; retardo do crescimento fetal; recém-nascido prematuro. 